\title{
Optimization of Enrichment and Isolation Media of Thermophilic Hydrocarbonoclastic Bacteria Isolated from Oil Reservoir of West Java for Microbial Enhanced Oil Recovery (MEOR) Application
}

(Pengoptimuman Media Isolasi dan Pengkayaan Bakteria Hidrokarbonoklastik Termofili yang Dipencilkan daripada Takungan Minyak Jawa Barat untuk Aplikasi Perolehan Kembali Minyak Galakan Mikrob (MEOR))

\section{Dea Indriani Astuti, Isty AdHitya Purwasena*, Gregorius Gilang SATrio, Kelvin Rachmad Andika, GHaida Zainiya Millati, Tera WAHYu DWiningrum \& EVITA MERIANi}

\begin{abstract}
Microbial enhanced oil recovery (MEOR) is a tertiary oil recovery process which aims to increase the crude oil recovery uptake to 55\% from its original oil in place. In its application, indigenous microorganisms are commonly used as the main biological agents, but the isolation processes become more complicated due to environment's extreme condition. This study aims to determine the optimum formulation for the enrichment and isolation medium, in order to obtain a highly diverse of indigenous hydrocarbonoclastic bacteria. The isolation process was carried out in two stages; the isolation of mild oil fraction degrading bacteria, and isolation of the heavy oil fraction degrading bacteria which confirmed by the SARA (saturated, aromatic, resinic, and asphaltic) fraction chromatography analysis. Four enrichment and five isolation media were formulated based on the distinction in the macro-and micronutrient composition. Overall, a total of 92 isolates were successfully isolated. The highest bacterial diversities were achieved in the enrichment medium B (crude oil used as carbon source which supplemented with sodium lactate) and isolation medium I (nutrient agar with twice agar concentration), each with 37 and 33\% of obtained isolates, respectively. The newly formulated medium can be further utilized to isolate various types of indigenous bacteria from the oil well which were able to degrade SARA fraction from crude oil. The result showed that ABG2-7 as the isolate with the highest activity on SARA degradation. The amount of 15\% inoculum of ABG2-7 isolate was able to degrade heavy crude oil, thus might serve as potential bacteria for MEOR application.
\end{abstract}

Keywords: Bacterial diversities; enrichment media; isolation media; MEOR

\section{ABSTRAK}

Perolehan kembali minyak galakan mikrob (MEOR) merupakan proses perolehan kembali minyak tertier yang bertujuan untuk meningkatkan perolehan kembali minyak mentah sehingga 55\%. Mikroorganisma asli umumnya digunakan sebagai agen biologi tetapi proses pengasingan mikroorganisma tidak mudah untuk dilakukan kerana keadaan persekitaran yang ekstrim. Penyelidikan ini bertujuan untuk menentukan pengoptimuman media pengasingan dan pengkayaan bakteria bagi mendapatkan bakteria hidrokarbonoklastik yang asli. Proses pengasingan dilakukan dalam 2 tahap iaitu pengasingan bakteria yang mendegradasi pecahan minyak secara berat atau ringan dan disahkan dengan melakukan analisis kromatografi SARA (ketepuan, aromatik, resin dan asfaltena). Sebanyak 4 media pengkayaan dan 5 media pengasingan diformulasikan berdasarkan komposisi pembezaan pada mikro dan makro nutrien. Hasilnya, sebanyak 92 sampel pencilan berjaya diasingkan. Sampel pencilan tertinggi adalah pada sampel media B (minyak mentah yang mempunyai natrium laktat digunakan sebagai sumber karbon) dan media I (agar bernutrien dengan kepekatan 2 kali ganda) masing-masing dengan 37 dan 33\% pencilan. Melalui medium ini juga, terdapat pelbagai jenis bakteria asli daripada takungan minyak boleh diasingkan kerana bakteria ini mampu mendegradasikan SARA daripada minyak mentah. Hasil menunjukkan sampel pencilan ABG2-7 memiliki kemampuan yang terbaik dalam mendegradasi SARA. Jumlah inokulum paling optimum daripada pencilan ABG2-7 yang digunakan untuk mendegradasi pecahan berat minyak mentah adalah sebanyak 15\%, sekaligus berpotensi sebagai bakteria yang boleh digunakan untuk aplikasi MEOR.

Kata kunci: Kepelbagaian bakteria; media perkayaan; media pengasingan; MEOR 


\section{INTRODUCTION}

The oil reservoir is commonly characterized as an extreme environment with high temperature, pressure and salinity, and anoxic. However, research in the last few decades has shown that oil reservoir contained some active and diverse microbial communities which determine the quality and quantity of crude oil recovery. Much attention towards the microbiological aspects related to the oil reservoir comes not only from academia but also from the oil industry because of their scientific significance and industrial application. Major attention has been paid to isolate bacteria for MEOR. MEOR is one of the tertiary oil recovery technologies exploiting the use of reservoir bacteria or specially selected natural bacteria to produce specific metabolic in order to enhance oil recovery ( $\mathrm{Ke}$ et al. 2018). Indigenous petroleum microorganisms are commonly used as the main biological agents for MEOR application (Ariadji et al. 2017), however, the extreme environmental condition of the reservoir causes the microbial abundance relatively small and the isolation process becomes more complicated (Kamagata 2015). Although large number of microorganisms have been isolated from oil reservoirs, isolation of hydrocarbon degrading bacteria still remained a substantial challenge (Davidova \& Sulfita 2005).

At the beginning, the main focus of oil reservoir studies was mainly related to culture-based approach, as reported by Olliver and Cayol (2005), Purwasena et al. (2014) and Röling et al. (2003). Approximately, $0.1-15 \%$ of the total microbial communities are culturable (Amman et al. 1995). Since the number of culturable microorganism in laboratory is very limited, this approach cannot be employed to clearly describe the in-situ microbial communities which are available in the oil reservoir. Recent progress in microbiology resulted in the application of molecular biology in culture-independent techniques that has been shown to be more effective to characterize the microbial community assemblages from the environmental samples (Kemp \& Aller 2004). However, these molecular techniques are still developing, thus, physiological characteristics of the microorganism are remained to be explored. The role of uncultured microorganism in the oil reservoir which is detected by the available techniques cannot be fully understood until these microorganisms are available for detailed physiological and molecular analysis.

The lack of success in isolating novel bacteria from natural environments is mainly due to the physiology of not-yet-cultured bacteria. Therefore, it is important to meet the requirements for growing the targeted bacteria in enrichment culture experiments for the successful isolation. Nonetheless, it seems necessary to develop novel approaches and modifications of conventional isolation techniques to isolate novel targeted bacteria.

Synthetic mineral media and artificially controlled conditions have been commonly used for isolating bacteria from natural environment such as oil reservoirs. Madigan and Martinko (2006) suggested that the enrichment culture conditions should be duplicated closely to the condition of the original habitat of targeted bacteria. To isolate the targeted bacteria from the reservoir brine, growth conditions such as temperature, pressure, $\mathrm{pH}$, organic and/or inorganic components, and atomospheric condition should be identical with those in oil reservoir (Halim et al. 2009; Röling et al. 2003). Indigenoeus hydrocarbonoclastic bacteria which is able to degrade heavier fraction of crude oil are preferable for MEOR application. These types of bacteria can decrease the crude oil viscosity by degrading heavier fraction of crude oil so that increase the composition of light fraction. Under this circumstance, the oil mobility will be increase which causing the improvement of overall oil recovery process (Purwasena et al. 2009). Therefore, the bacterial isolation is important to be carried out based on the composition of hydrocarbon components. One method of oil characterization is the separation of crude oil components into saturated, aromatic, resin, and asphalt (SARA fractionation) (Aske et al. 2001).

This research is aimed to find enrichment and isolation medium to obtain a high diversity of the isolated of indigenous hydrocarbonoclastic bacteria from oil wells. The isolation process was carried out in two-stage where the first-stage was intended to isolate the mild oil fraction degrading bacteria while the second-stage was to isolate the heavy fraction degrading bacteria, which confirmed by SARA fraction chromatography analysis.

\section{MATERIALS AND METHODS}

\section{OIL SAMPLE COLLECTION AND CHARACTERIZATION}

Oil sample was taken from ' $\mathrm{X}$ ' oil field wells under the name of ABG-02. Sample was collected in 500 $\mathrm{mL}$ air-tight Schott laboratory bottles. For anaerobic sample, bottles were flushed with nitrogen gas prior to sampling and filled to its full capacity to maintain oxygen-free environment. Physical characteristics of crude oil were taken from Pertamina database while chemical characterization was done by environmental engineering water quality laboratory of Bandung Institute of Technology following the Standards Method for Waste and Wastewater (SMWW, USA). Additional physical characteristics (oil viscosity and interfacial tensions) were done with the assistance of Physical Chemistry laboratory of Bandung Institute of Technology. 
ENRICHMENT AND ISOLATION OF

HYDROCARBONOCLASTIC MICROORGANISMS

Prior to isolation, sample was enriched to increase its initial microbial load (Kamagata 2015). Four types of enrichment medium (Table 1) were used, then microbial isolation were done in five types of medium (Table 2). Enrichment was done in two-stages. First stage enrichment was done by incubating culture in $50{ }^{\circ} \mathrm{C}$ at $120 \mathrm{rpm}$ for 14 days. The remaining oil from the first stage enrichment was then used at the second stage. It should contain higher amount of heavy fraction of crude oil so that it used to isolate bacteria that capable to degrade heavier oil fraction. Second stage enrichment was also carried out for 14 days. Isolation was conducted at $37{ }^{\circ} \mathrm{C}$ every two days during enrichment period. Thermophilic isolates that capable to grow at $50{ }^{\circ} \mathrm{C}$ were then obtained through thermal adaptation (Mandri \& Lin 2007). Solid-culture of isolated microorganism grown in $37{ }^{\circ} \mathrm{C}$ were inoculated into SMSS broth and incubated in gradually increasing temperature from $37^{\circ} \mathrm{C}$ to $50^{\circ} \mathrm{C}$ at $120 \mathrm{rpm}$. Stone Mineral Salt Solution (SMSS) medium consisted of, per liter, 2.5 $\mathrm{g} \mathrm{NH}_{4} \mathrm{NO}_{3}, 0.5 \mathrm{~g} \mathrm{MgSO}_{4} \cdot 7 \mathrm{H}_{2} \mathrm{O}, 0.2 \mathrm{~g} \mathrm{MnCl}_{2} \cdot 4 \mathrm{H}_{2} \mathrm{O}, 0.5 \mathrm{~g}$ $\mathrm{CaCO}_{3}, 1 \mathrm{~g} \mathrm{Na}_{2} \mathrm{HPO}_{4} .7 \mathrm{H}_{2} \mathrm{O}, 0.5 \mathrm{~g} \mathrm{KH}_{2} \mathrm{PO}_{4}$ with $0.1 \%$ (w/v) yeast extract and $2 \%(\mathrm{v} / \mathrm{v})$ crude oil (sterile) as the sole carbon source.

\section{SEPARATION OF CRUDE OIL BY SARA ASSAY}

Hydrocarbonoclastic properties of microorganism were confirmed by the change in the SARA profiles (Yernazarova et al. 2016). Crude oil components from the end of incubation of each isolation stage were separated using silica gel column chromatography. The remaining oil-degraded from the first-stage and second-stage of isolation was dissolved in $10 \mathrm{~mL}$ of $\mathrm{n}$-hexane. The insoluble fraction (asphaltic) was filtered using Whatman No. 1 filter and weighed. The soluble fraction (maltenes) was loaded on top of silica gel G (70-120 mesh) column $(2 \times 30 \mathrm{~cm})$ and eluted using three different solvents based on its polarity. The saturated fraction was eluted with hexane; aromatic fraction was eluted with thinner WS 80 , and resin fraction was eluted with thinner: methanol (90:10). All fraction obtained from samples was evaporated and weighed (Astuti et al. 2017).

\section{SCREENING OF POTENTIAL OIL-DEGRADING BACTERIA USING RESAZURIN ASSAY}

Bacterial isolates that survived from $50{ }^{\circ} \mathrm{C}$ incubation were further screened by resazurin assay. Luria Bertani Broth (LB broth) were used and incubated at $50{ }^{\circ} \mathrm{C}$ with $120 \mathrm{rpm}$ for 48 h. $10 \%$ of activated bacteria were then adapted into SMSS medium supplemented with 5\% $(\mathrm{v} / \mathrm{v})$ sterile crude oil and $0.1 \%(\mathrm{w} / \mathrm{v})$ yeast extract. The cultures were incubated at $50{ }^{\circ} \mathrm{C}$ with $120 \mathrm{rpm}$ for $48 \mathrm{~h}$.
$10 \%$ of adapted cultures were then inoculated into SMSS medium supplemented with $5 \%(\mathrm{v} / \mathrm{v})$ sterile crude oil, $0.1 \%(\mathrm{w} / \mathrm{v})$ yeast extract and resazurin $(4 \mathrm{mg} / \mathrm{L})$. The cultures were then incubated at $50{ }^{\circ} \mathrm{C}$ with $120 \mathrm{rpm}$ for 7 days. Resazurin's color change from blue, pink to colorless was monitored for every $24 \mathrm{~h}$ and it was indicated as the degradation rate (Modified from Astuti et al. (2017) and Benedek et al. (2010)).

\section{SCREENING AND SELECTION OF CRUDE-OIL-DEGRADING BACTERIA}

Six bacterial isolates with the highest crude-oil degradation rate were chosen for further selection. Selection was done based on the capacity of bacteria to degrade heavy oil fraction, such as resins and asphaltenes, which was determined by performing SARA fractions determination prior to and after 7 days of incubation in crude oil-enriched SMSS medium. During the incubation, bacterial cultures were agitated in $250 \mathrm{~mL}$ Erlenmeyer flask at $120 \mathrm{rpm}, 50{ }^{\circ} \mathrm{C}$. SARA fractions of the crude oil were determined using gravimetric and liquid chromatography method.

OPTIMAL INOCULUM CONCENTRATION DETERMINATION Two isolates that showed the best heavy oil fraction degradation property were further investigated to determine the inoculum concentration which yield the highest oil degradation capacity based on growth, SARA assay, and viscosity. The cultivation of the selected isolate was done in duplicate in $125 \mathrm{~mL}$ Erlenmeyer flask. Each contained $50 \mathrm{~mL}$ of SMSS medium enriched with 0 to $15 \%(\mathrm{w} / \mathrm{v})$ yeast extract and $3 \%(\mathrm{v} / \mathrm{v})$ independently autoclave-sterilized crude oil. Bacterial inoculum concentration is varied as follows: $10,12.5$ and $15 \%(\mathrm{v} / \mathrm{v})$. The cultures were constantly agitated at $120 \mathrm{rpm}$ in $50{ }^{\circ} \mathrm{C}$ incubator for $120 \mathrm{~h}$. SARA fractions and viscosity of all inoculum concentration were determined prior to and after the cultivation.

\section{RESULTS AND DISCUSSION}

\section{WELL ' $\mathrm{X}$ ' CHARACTERISTIC}

The oil sample physical and chemical characteristics were shown on Table 3. According to the results, it can be inferred from the physical characteristic (API values) that oil well ' $\mathrm{X}$ ' was categorized as a medium crude oil (Santos et al. 2014). The high-temperature indicates that it supported the growth of indigenous thermophilic microbial population (Madigan et al. 2015). The N-compounds ratio (nitrate, nitrite, ammonia) found in the oil might indicate that there was a very low oxygen level within the $\mathrm{X}$ well. This assumption was further confirmed by the low concentration of ferric ion compared to ferrous ion (Hedin \& Watzlaf 
1994). The low availability of organic compounds indicate that the indigenous microbial population was possibly predominated by hydrocarbonoclastic microorganisms (Ghribi et al. 2004). From the S-compounds, it can be observed that there was a high level of sulfates compared with sulfides. This might indicate that there was a high possibility for sulfate-reducing bacteria (SRB) to grow and proliferate (Davidova et al. 2001).

HYDROCARBONOCLASTIC MICROBIAL ISOLATES

The highest bacterial diversities were obtained in the enrichment medium B and isolation with medium I, each with 37 and $33 \%$ of total obtained isolates as shown in Figure 1. A total of 92 isolates was obtained from the two-stage isolation procedure. A total of 77 isolates were successfully obtained from the first stage of isolation and the remaining 15 isolates were obtained from the next stage. It is suspected that 15 isolates taken from the second stage are considered as hydrocarbonoclastic microorganism that capable of degrading heavier oil fraction, which indicates a potential application of these isolates for MEOR and bioremediation.

Thermal adaptation was done prior to screen the microorganism which capable to thrive under elevated temperature. This procedure was done to prevent heatshock that would result in the failure of isolation process. A total of 46 thermophilic hydrocarbonoclastic bacterium isolates were obtained after thermal adaptation.

A total of 38 isolates was obtained from the first stage of isolation and the remaining 8 isolates were obtained from the second stage. The morphological characteristics of these isolates were shown in Table 4.

Crude oil is a complex mixture of vast arrays of hydrocarbons ranging from simple, easily bio-degraded fraction n-alkanes to recalcitrant compound, such as branched or cyclic alkanes (Spini et al. 2018). High prevalence of oil fields that contained indigenous microorganisms which capable to degrade oil fraction might be a result of selective pressure that causes microorganism equipped with specific enzymes to degrade complex hydrocarbon in order to thrive within the site (Lacy 1987). These microorganisms, however, are found in a small number substantially because of the sub-optimum nutrients availability and climatic factors that yield inefficient enzymatic activity of these organisms. Each microorganisms requires specific $\mathrm{C}: \mathrm{N}: \mathrm{P}$ ratio and other suitable environmental parameters to perform at its highest ability (Sarkar et al. 2016; Xu et al. 2018). By means of nutrient adjustments through enrichment procedure, many of these microorganisms could grow at an elevated rate thus enabling microbial isolation as shown by the result of isolation procedure. Experiment showed that addition of $2 \%(\mathrm{v} / \mathrm{v})$ sodium lactate to SMSS medium containing minerals and $0.1 \%$ of yeast (w/v) extract as nitrogen source resulted in higher varieties of microorganisms that could be succesfully isolated. It was presumed that the addition of lactate, yeast extract and phosphate in anorganic form leads to appropriate $\mathrm{C}: \mathrm{N}: \mathrm{P}$ ratio which allow indigenous microorganism to grow better ex-situ.

\section{SEPARATION OF SARA COMPONENTS OF CRUDE OIL BY COLUMN CHROMATOGRAPHY}

The results of SARA fractionation showed the occurrence of mild fraction degradation, such as the alkanes fraction at the first stage and the degradation of heavy fractions such as aromatics at the second stage as shown in Figure 2. To ensure that hydrocarbonoclastic bacteria were succesfully obtained from the sequential isolation, SARA assay was performed with crude oil from the first-stage and second-stage isolation were used as sample. Crude oil without bacteria treatment was used as control. This method classifies crude oil based on their fraction polarity through a chromatographic technique that divides oil into four main fractions, which are saturated, aromatic, resinic, and asphaltic (Santos et al. 2014). Degradation level of different hydrocarbon fractions are affected by oil characteristics and capability of microorganism to degrade different classes of fraction (Gailiūtè et al. 2014). The result showed in Figure 2 provides the information that there were some altered compositions in SARA fractions from the first-stage and second-stage isolation compared with control. It was expected that all obtained isolates possess the potential degradation toward all fractions. Saturated fraction was a major fraction in the crude oil, followed by asphaltic fraction. Compared with control, asphaltic and saturated fraction were relatively decreased. Saturated fraction is easily degraded by bacteria due to its higher polarity and solubility among all fractions. Resinic and asphaltic are considered difficult to degrade due to their high molecular weight, aromaticity, polarity, molecular weight, and heteroatom contents (Islas-Flores 2005). There are several mechanisms that involved in biodegradation of petroleum hydrocarbons, such as the attachment of microbial cells to the substrates, specific enzyme system (i.e oxygenase) and production of biosurfactants (Das \& Chandran 2011).

\section{POTENTIAL OIL DEGRADING BACTERIA USING RESAZURIN} ASSAY

Resazurin assay served as a redox indicator to observe cell viability in growth media. Living cells have active metabolites and able to reduce resazurin, the nonfluorescent to the strongly-fluorescent dye resorufin. Resazurin can also be served as an indicator for bacterial 
inactivity, as inactive bacteria caused no change in resazurin color. Screening results showed that there were 6 isolates which appeared to have rapid resazurin color change; ABG2-7, ABG2-26, ABG2-45, ABG2-52, ABG254 , and $A B G 2-62$. Those isolates were chosen as potential hydrocarbon degrading bacteria. Crude oil degradation occurred in aerobic condition where oxygenase enzyme is involved as part of biodegradation process, as this enzyme is required to introduce oxygen in the substrate to initiate biodegradation (Das \& Chandran 2011).

\section{SCREENING AND SELECTION OF CRUDE-OIL-DEGRADING BACTERIA}

Based on SARA fractions of post-treated crude oil (Figure 3 ), most isolates showed a tendency to degrade asphaltenes fraction. ABG2-54 isolate showed a slight degradation activity, whereas crude oil treated with isolate ABG27 and ABG2-26 demonstrated the highest asphaltene degradation activity. However, in addition to asphaltenes, other fractions such as resinic and aromatic fractions were also degraded to higher extent by ABG2-7. On the other hand, ABG2-47 isolate caused a significant reduction in aromatics fractions, while asphaltenes fraction decreased up to $14.48 \%$. Bacteria can degrade petroleum components specifically with different metabolic pathways according to the enzymes secreted by each bacterium. In aerobic conditions, hydrocarbons will be oxidized using enzyme monooxygenase or dioxygenase secreted by the bacteria (Sierra-Garcia \& de Oliveira 2013). Being relatively recalcitrant and heavy (Gailiūtè et al. 2014), the degradation process of asphaltenes, resins, and aromatics fraction of crude oil is considered paramount to EOR practices (Shibulal et al. 2018). Thus, ABG2-7 and ABG2-47 were chosen for further analysis. In addition, microbial consortium can promote complete degradation of hydrocarbon fractions (Aditiawati \& Kamarisima 2015). Therefore, ABG2-7 and ABG2-47 isolate were showed as the potential oil- degrading bacteria consortium.

\section{DETERMINATION OF OPTIMAL INOCULUM CONCENTRATION}

The optimum inoculum concentration was determined by analyzing the performance of single $\mathrm{ABG} 2-7$ isolate and ABG2-7:47 consortium based on SARA assay, viscosity, and growth. SARA fractions of post-treated crude oil showed that at $15 \%$ of inoculum concentration resulted in the highest asphaltene degradation activity of ABG2-7 isolate while $10 \%$ of inoculum concentration showed a marked decrease in resinic fraction (Figure 4(A)). Midconcentration at $12.5 \%$ yielded only a slight change in crude-oil fractions indicating sub-optimal inoculum density for oil degradation. The observed alteration of crude oil fractions was in line with the post-treatment viscosity measurements (Figure 4(B)).

Compared with bacterial consortium of ABG2-7:47, there was not much significant difference between SARA fractions of post-treated crude oil and viscosity from individual isolate performed by ABG2-7. This result was in concomittant with the result of ABG2-7:47 consortium growth curve (Figure 4(C)) from different inoculum percentage $(10,12.5, \& 15 \%)$ which has growth rate lower than individual ABG2-7 isolate (10\%) of around $10^{7.0}$ - $10^{7.5} \mathrm{cfu} / \mathrm{mL}$. Furthermore, generation time and specific growth between ABG2-7:47 consortium and ABG2-7 individual isolate indicated a similarity of about $3 \mathrm{~h}$ and $0.2-0.3$ per hour, respectively (Table 5). We assumed that both isolates consumed the same source of carbon in order to grow. Thus, there might be a competition in utilizing nutrition source that limits the bioavailability for the biodegradation of crude oil (Riss et al. 2016).

In comparison to control, ABG2-7 with $15 \%(\mathrm{v} / \mathrm{v})$ inoculum showed the highest reduction of viscosity (4.19 cP) and lowest percentage of asphaltenes fraction to $17.52 \%$. However, the result showed by the growth curve describes that ABG2-7 (10\%) has the highest density of cells of $10^{8} \mathrm{cfu} / \mathrm{mL}$ up until $120 \mathrm{~h}$ incubation period. Growth curve, specific growth and generation time data indicated that ABG2-7 isolate posses a high number of cell that grown under crude oil as sole source of carbon that prolonged up to $120 \mathrm{~h}$ incubation.

Based on SARA test, ABG2-7 (10\%) isolate successfully degraded aromatics fraction to $5.22 \%$ whereas ABG2-7 (15\%) degraded asphaltenes to $17.52 \%$. According to Gailiūtè et al. (2014), asphaltenes has more complex structure and degraded more slowly compared with aromatics fraction which considered as more biodegradable component. Therefore, ABG2-7 (15\%) has lower growth rate than ABG2-7 (10\%) since it might be difficult to utilize complex substrate which occurred in low bioavailability. In addition, it is possibly thought that the highest viscosity reduction by ABG2-7 (15\%) was due to asphaltenes higher contribution in crude oil viscosity.

According to Gailiūtè et al. (2014), microbial systems which are capable to biologically transform heavier oil fractions, e.g. asphaltene and resin, are best used in old oil reservoirs to increase the oil recovery rate by reducing oil viscosity. Despite possible upshot of fast nutrient depletion in higher inoculum density (Maliji et al. 2013), the inoculum percentage was considered as an important factor as it demonstrated significant influence in degrading heavier crude oil fractions. Therefore, 15\% $(\mathrm{v} / \mathrm{v})$ inoculum was chosen as the optimum inoculum concentration. 

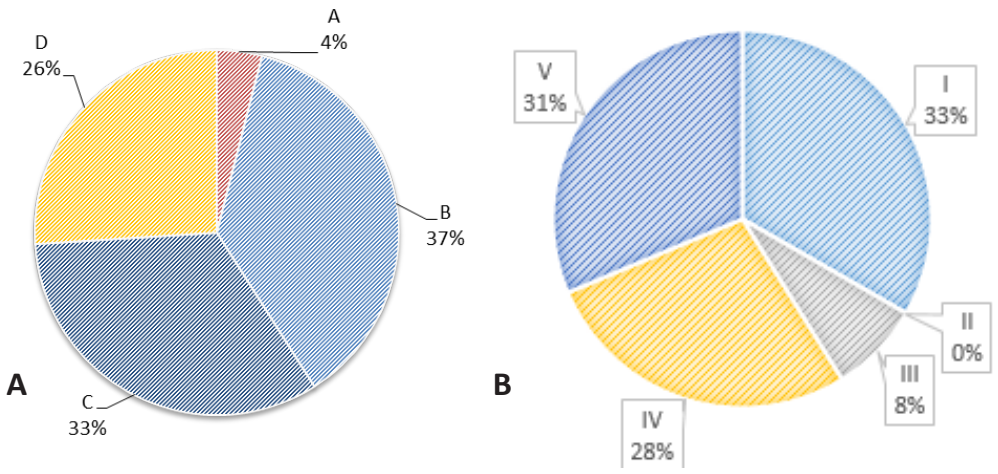

FIGURE 1. Diversities of bacterial isolates obtained based on (A) Enrichment media (B) Isolation media

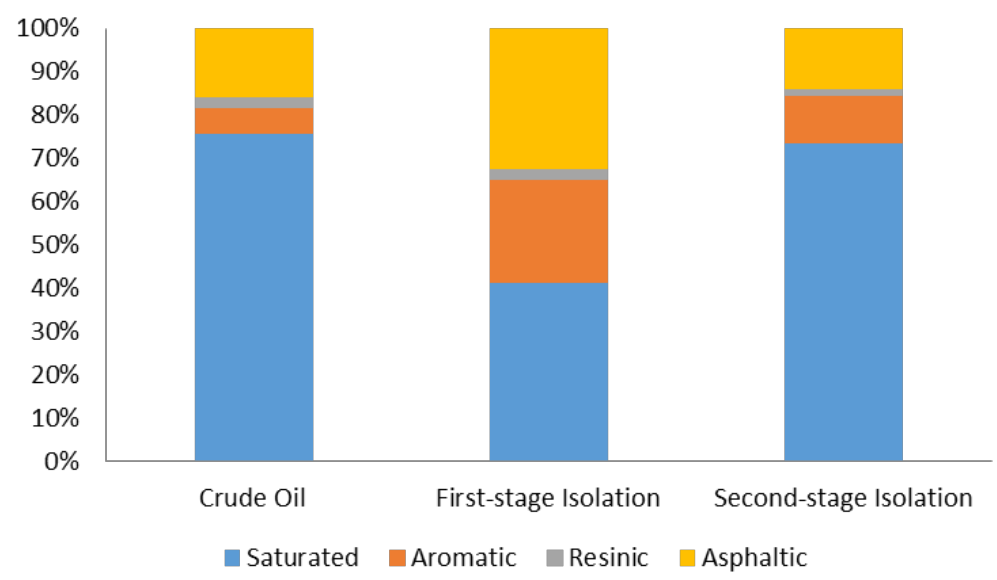

FIGURE 2. Result of SARA fractionation using the redisudal crude oil after first and second-stage isolation

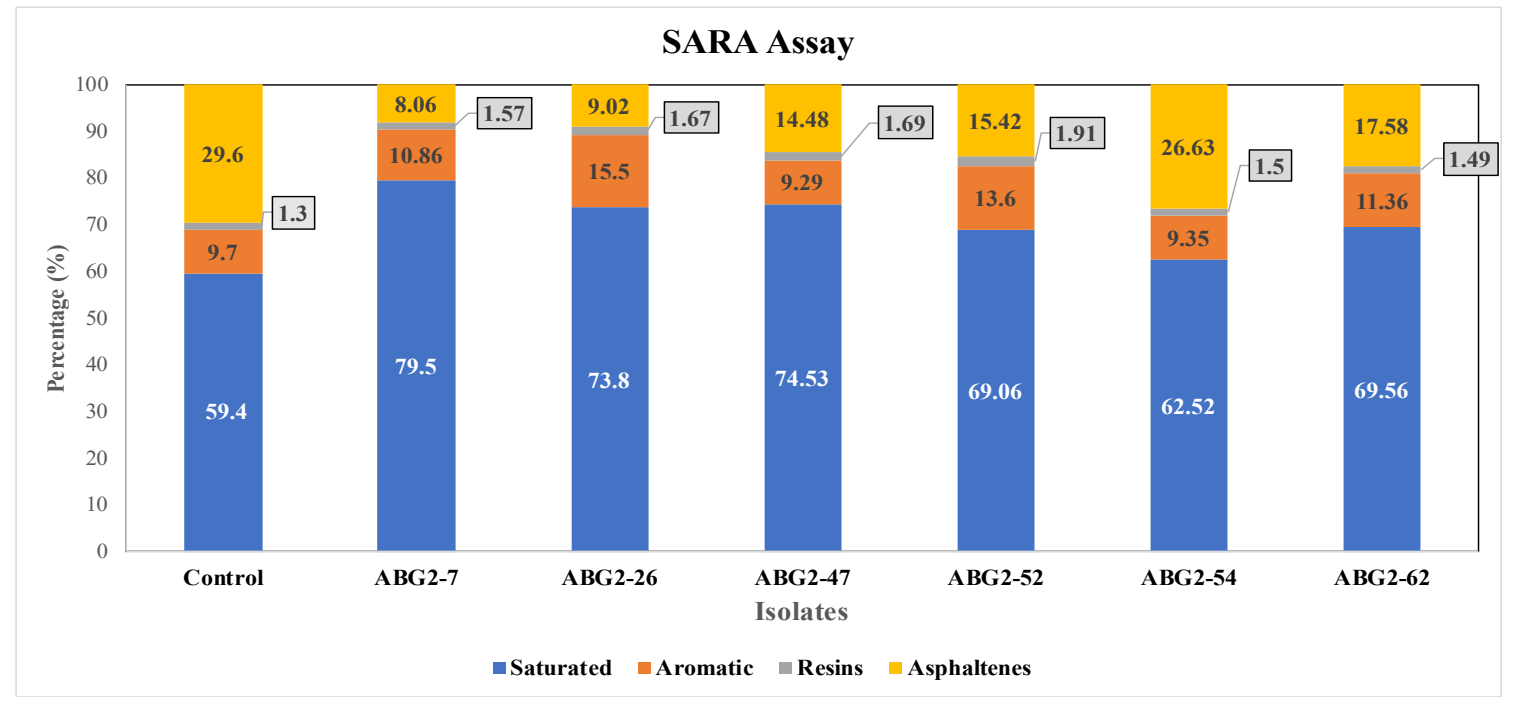

FIGURE 3. Post-treated SARA fractions of crude oil 
SARA Inoculum Percentage Variation

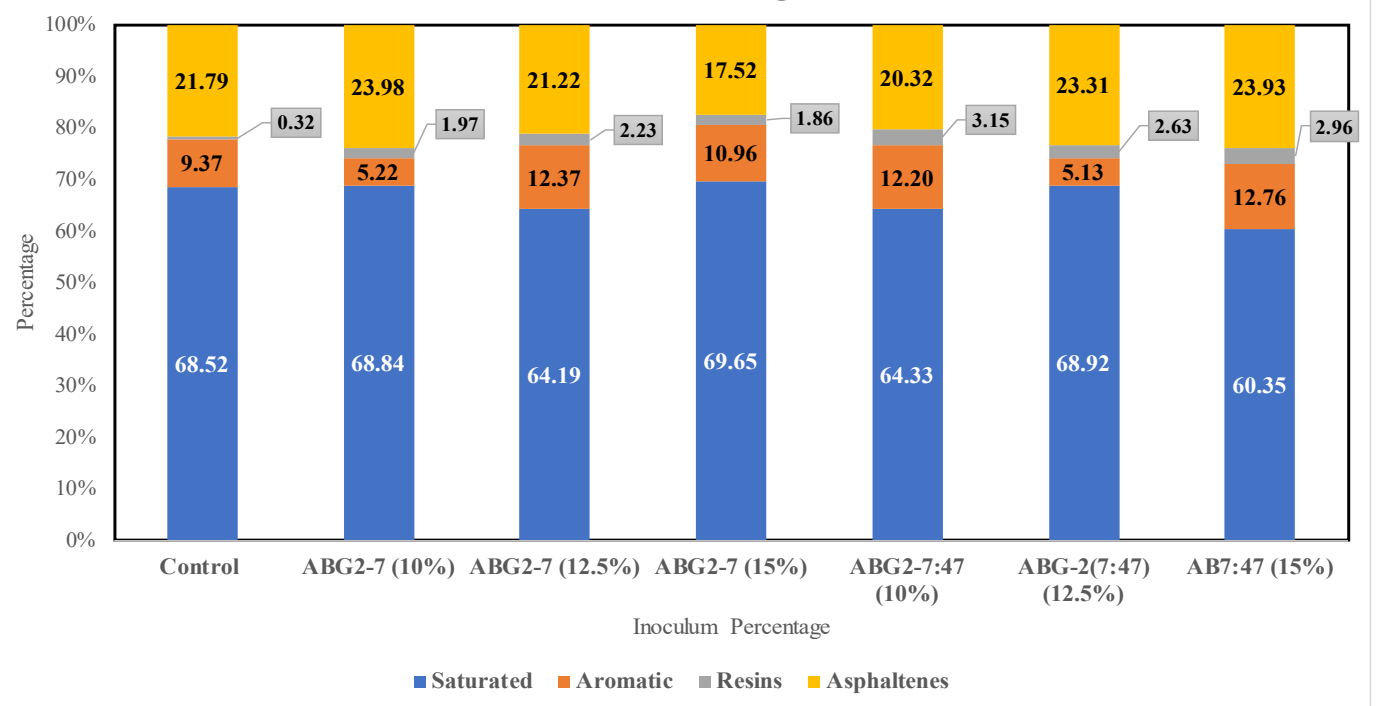

(A)

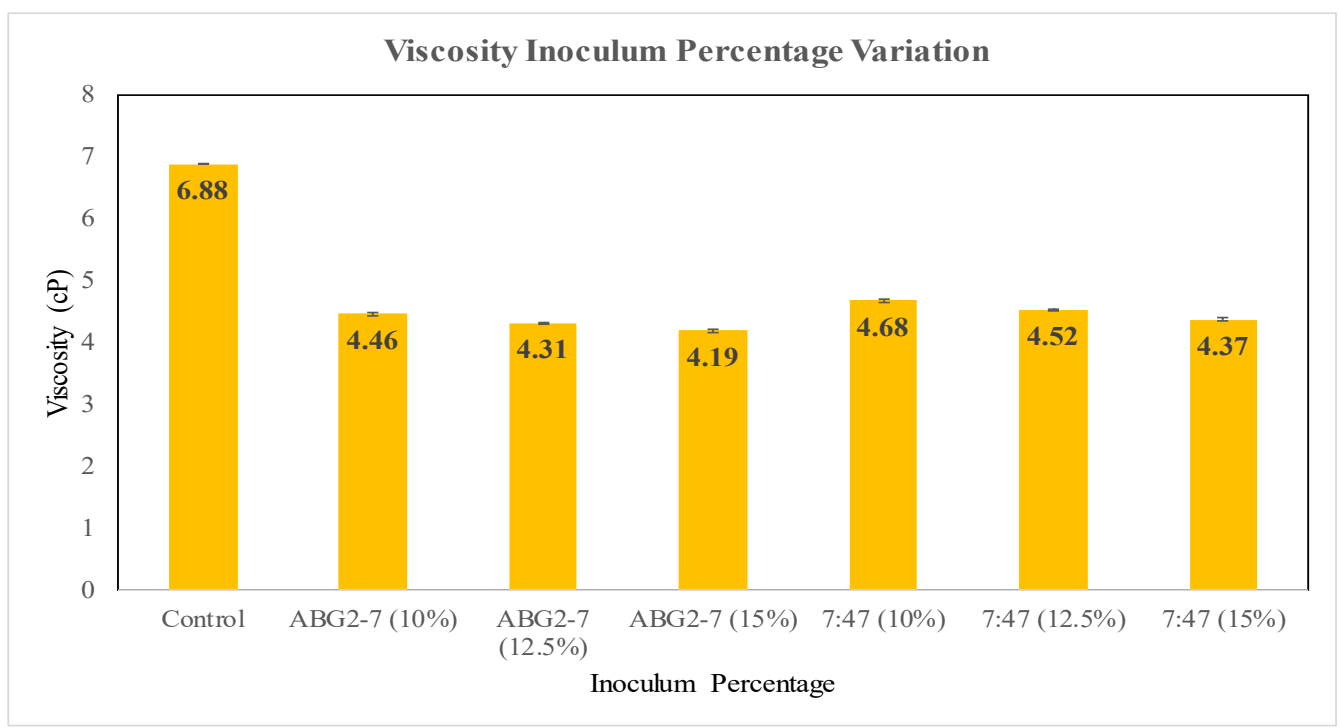

(B)

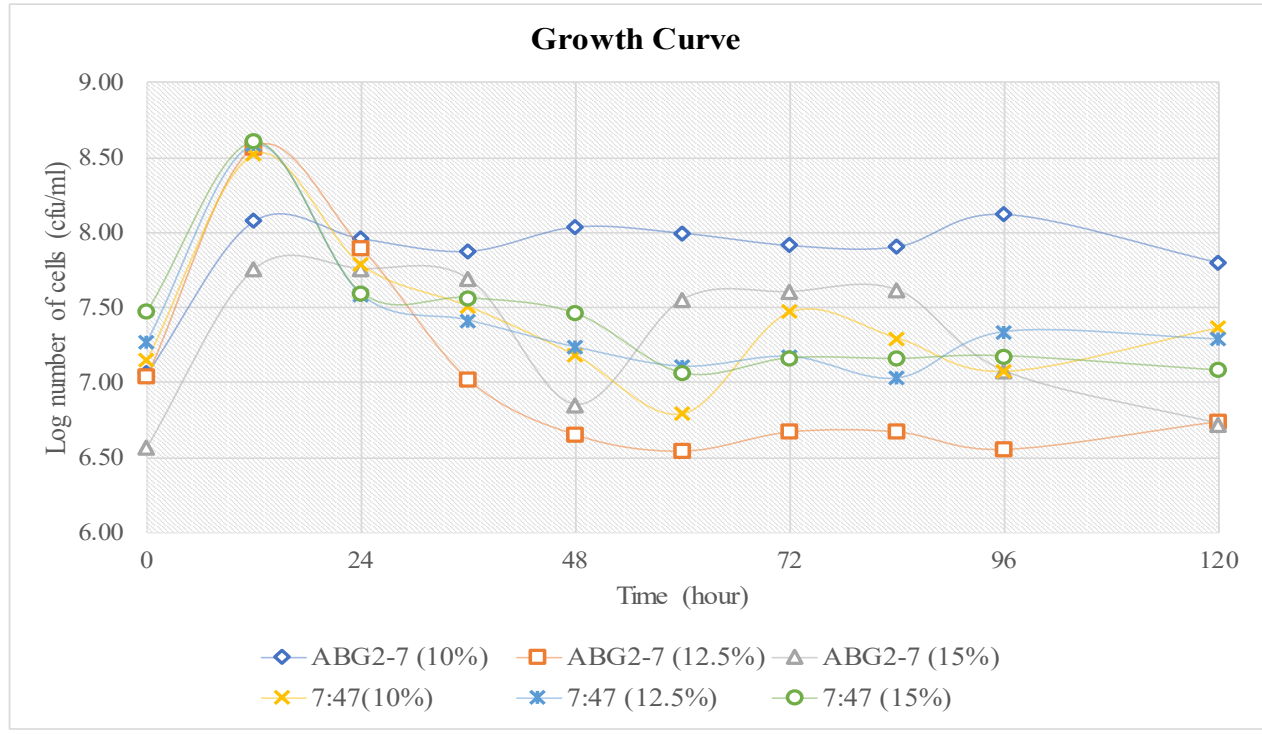

(C)

FIGURE 4. (A) SARA fractions of post-treated crude oil, (B) viscosity, and (C) growth curve 
TABLE 1. Enrichment media used in sample enrichment

\begin{tabular}{cc}
\hline Medium & Component \\
\hline I & $2 \%$ of unsterilized oil + Stone salt mineral medium $(\mathrm{SMSS})$ \\
II & $2 \%$ of sodium lactate $+2 \%$ unsterilized oil + SMSS \\
III & $2 \%$ of sterilized oil $+1 \%$ yeast extract $(\mathrm{w} / \mathrm{v})+$ unsterilized brine \\
IV & $2 \%$ of sodium lactate $+1 \%$ yeast extract $(\mathrm{w} / \mathrm{v})+$ unsterilized brine \\
\hline
\end{tabular}

TABLE 2. Isolation media used in enrichment culture isolation

\begin{tabular}{cc}
\hline Medium & Component \\
\hline I & Nutrient-agar $(2 \mathrm{X}$ agar $)$ \\
II & $2 \%$ of sodium lactate + SMSS \\
III & $2 \%$ sodium lactate $(\mathrm{v} / \mathrm{v})+$ Autoclaved-sterilized brine \\
IV & $2 \%$ of sodium lactate $+1 \%$ yeast extract $(\mathrm{w} / \mathrm{v})+$ filter-sterilized brine \\
V & Nutrient agar $(1 / 2 \mathrm{X}$ agar $)$ \\
\hline
\end{tabular}

TABLE 3. Physical and chemical characteristic of abg-02 reservoir fluids

\begin{tabular}{|c|c|}
\hline Parameter & Value \\
\hline \multicolumn{2}{|c|}{ Brine/Formation water } \\
\hline Conductivity & $28000 \mu \mathrm{S} / \mathrm{cm}$ \\
\hline Salinity & $15.7 \%$ \\
\hline Total iron $(\mathrm{Fe})$ & $1.04 \mathrm{mg} / \mathrm{L}$ \\
\hline Ferrous iron $\left(\mathrm{Fe}^{2+}\right)$ & $0.559 \mathrm{mg} / \mathrm{L}$ \\
\hline Ferric iron $\left(\mathrm{Fe}^{3+}\right)$ & $0.481 \mathrm{mg} / \mathrm{L}$ \\
\hline Chloride $\left(\mathrm{Cl}^{-}\right)$ & $8144 \mathrm{mg} / \mathrm{L}$ \\
\hline Alkalinity $\left(\mathrm{CaCO}_{3}\right)$ & $1066 \mathrm{mg} / \mathrm{L}$ \\
\hline Calsium $(\mathrm{Ca})$ & $224 \mathrm{mg} / \mathrm{L}$ \\
\hline Nitrate & $0.019 \mathrm{mg} / \mathrm{L} \mathrm{NO} 3-\mathrm{N}$ \\
\hline Nitrite & $0.033 \mathrm{mg} / \mathrm{L} \mathrm{NO} 2-\mathrm{N}$ \\
\hline Ammonia & $17.6 \mathrm{NH}_{3}-\mathrm{N}$ \\
\hline Sulfate $\left(\mathrm{SO}_{4}\right)$ & $528 \mathrm{mg} / \mathrm{L}$ \\
\hline Sulfide $\left(\mathrm{H}_{2} \mathrm{~S}\right)$ & $<0.001 \mathrm{mg} / \mathrm{L}$ \\
\hline Organic material & $0.149 \mathrm{mg} / \mathrm{L}$ \\
\hline Carbonate $\left(\mathrm{CO}_{3}\right)$ & $0.0 \mathrm{mg} / \mathrm{L}$ \\
\hline Bicarbonate $\left(\mathrm{HCO}_{3}\right)$ & $76.5 \mathrm{mg} / \mathrm{L}$ \\
\hline Orthophosphate & $3.11 \mathrm{mg} / \mathrm{L}$ \\
\hline Total Phosphate & $4.27 \mathrm{mg} / \mathrm{L} \mathrm{P}$ \\
\hline Nitrogen NTK & $32.9 \mathrm{mg} / \mathrm{L}$ \\
\hline Total Chromium (Cr) & $<0.001 \mathrm{mg} / \mathrm{L}$ \\
\hline Nickel & $<0.001 \mathrm{mg} / \mathrm{L}$ \\
\hline \multicolumn{2}{|c|}{ Crude oil } \\
\hline Viscosity & $1.33334 \mathrm{cP}$ \\
\hline Interfacial Tension & 29.8 dyne/cm \\
\hline API & $24.337^{\circ}$ \\
\hline Reservoir temperature & $80^{\circ} \mathrm{C}$ \\
\hline
\end{tabular}


TABLE 4. Thermophilic hydrocarbonoclastic bacterial isolates obtained after the thermal adaptation

\begin{tabular}{|c|c|c|c|c|c|c|c|c|c|}
\hline \multirow{2}{*}{$\begin{array}{l}\text { Stage of } \\
\text { isolation }\end{array}$} & \multirow{2}{*}{ Isolates } & \multicolumn{6}{|c|}{ Macroscopic Morphology } & \multicolumn{2}{|c|}{$\begin{array}{l}\text { Microscopic } \\
\text { Morphology }\end{array}$} \\
\hline & & Shape & Elevation & Margin & Pigmentation & $\begin{array}{c}\text { Optical } \\
\text { Property }\end{array}$ & Appearance & Gram & Shape \\
\hline \multirow{38}{*}{ I } & ABG1 & Irregular & Umbonate & Undulate & Cream & Translucent & Dull & - & Bacilli \\
\hline & ABG2 & Irregular & Raised & Curled & Cream & Translucent & Dull & + & Bacilli \\
\hline & ABG3 & Circular & Convex & Entire & Orange & Opaque & Dull & - & Bacilli \\
\hline & ABG4 & Circular & Convex & Entire & Yellow & Opaque & Shiny & - & Bacilli \\
\hline & ABG5 & Circular & Umbonate & Entire & Cream & Opaque & Shiny & + & Bacilli \\
\hline & ABG6 & Circular & Convex & Entire & White & Opaque & Dull & + & Bacilli \\
\hline & ABG7 & Irregular & Umbonate & Lobate & Tan & Opaque & Shiny & - & Bacilli \\
\hline & ABG8 & Circular & Convex & Entire & White & Opaque & Shiny & - & Bacilli \\
\hline & ABG9 & Circular & Convex & Entire & Cream & Opaque & Dull & - & Bacilli \\
\hline & ABG10 & Circular & Convex & Entire & Yellow & Opaque & Shiny & - & Bacilli \\
\hline & ABG11 & Circular & Convex & Entire & White & Opaque & Shiny & + & Bacilli \\
\hline & ABG12 & Irregular & Raised & Undulate & White & Opaque & Dull & - & Bacilli \\
\hline & ABG13 & Irregular & Raised & Undulate & White & Translucent & Dull & - & Bacilli \\
\hline & ABG14 & Irregular & Raised & Undulate & Cream & Opaque & Shiny & - & Bacilli \\
\hline & ABG15 & Irregular & Raised & Undulate & White & Translucent & Dull & - & Bacilli \\
\hline & ABG16 & Circular & Raised & Entire & Yellow & Opaque & Dull & - & Bacilli \\
\hline & ABG17 & Filament & Flat & Filiform & White & Translucent & Dull & - & Bacilli \\
\hline & ABG18 & Circular & Umbonate & Entire & Orange & Opaque & Shiny & - & Bacilli \\
\hline & ABG19 & Irregular & Flat & Filiform & White & Opaque & Dull & - & Bacilli \\
\hline & ABG20 & Irregular & Raised & Undulate & Yellow & Opaque & Shiny & - & Bacilli \\
\hline & ABG21 & Circular & Convex & Entire & Cream & Opaque & Shiny & - & Bacilli \\
\hline & ABG22 & Circular & Convex & Entire & White & Opaque & Shiny & - & Bacilli \\
\hline & ABG23 & Circular & Convex & Entire & White & Opaque & Shiny & - & Bacilli \\
\hline & ABG24 & Rhizoid & Raised & Rhizoid & Cream & Translucent & Dull & + & Bacilli \\
\hline & ABG25 & Circular & Raised & Entire & White & Opaque & Shiny & - & Bacilli \\
\hline & ABG26 & Circular & Convex & Entire & White & Opaque & Shiny & - & Cocci \\
\hline & ABG27 & Circular & Convex & Entire & Yellow & Opaque & Shiny & - & Cocci \\
\hline & ABG28 & Circular & Flat & Entire & Cream & Translucent & Shiny & - & Bacilli \\
\hline & ABG29 & Circular & Raised & Entire & Cream & Opaque & Shiny & - & Bacilli \\
\hline & ABG30 & Circular & Raised & Entire & Cream & Opaque & Shiny & + & Cocci \\
\hline & ABG31 & Circular & Raised & Entire & White & Opaque & Shiny & + & Cocci \\
\hline & ABG32 & Circular & Convex & Entire & Cream & Opaque & Shiny & + & Bacilli \\
\hline & ABG33 & Circular & Raised & Entire & Cream & Opaque & Shiny & + & Cocci \\
\hline & ABG34 & Circular & Convex & Entire & Cream & Opaque & Shiny & + & Bacilli \\
\hline & ABG35 & Irregular & Flat & Filament & Cream & Opaque & Dull & + & Bacilli \\
\hline & ABG36 & Irregular & Flat & Lobate & Cream & Opaque & Dull & - & Bacilli \\
\hline & ABG37 & Circular & Raised & Entire & Cream & Translucent & Shiny & + & Cocci \\
\hline & ABG38 & Irregular & Flat & Filament & Cream & Translucent & Dull & + & Bacilli \\
\hline
\end{tabular}




\begin{tabular}{|c|c|c|c|c|c|c|c|c|c|}
\hline & ABG39 & Circular & Flat & Entire & Cream & Translucent & Dull & + & Bacilli \\
\hline & ABG40 & Circular & Raised & Entire & Cream & Translucent & Shiny & + & Bacilli \\
\hline & ABG41 & Irregular & Flat & Undulate & Cream & Opaque & Dull & + & Bacilli \\
\hline \multirow{5}{*}{ II } & ABG42 & Circular & Flat & Entire & Cream & Translucent & Shiny & - & Bacilli \\
\hline & ABG43 & Filament & Filament & Raised & Cream & Translucent & Shiny & - & Bacilli \\
\hline & ABG44 & Circular & Convex & Entire & Cream & Translucent & Shiny & - & Bacilli \\
\hline & ABG45 & Filament & Filament & Flat & Cream & Opaque & Shiny & - & Bacilli \\
\hline & ABG46 & Filament & Filament & Flat & Cream & Opaque & Dull & - & Bacilli \\
\hline
\end{tabular}

TABLE 5. Generation time and specific growth of ABG2-7 individual isolate and ABG2-7:47 consortium

\begin{tabular}{ccccccc}
\hline & $\begin{array}{c}\text { ABG2-7 } \\
(10 \%)\end{array}$ & $\begin{array}{c}\text { ABG2-7 } \\
(12.5 \%)\end{array}$ & $\begin{array}{c}\text { ABG2-7 } \\
(15 \%)\end{array}$ & $\begin{array}{c}\text { ABG2-7:47 } \\
(10 \%)\end{array}$ & $\begin{array}{c}\text { ABG2-7:47 } \\
(12.5 \%)\end{array}$ & $\begin{array}{c}\text { ABG2-7:47 } \\
(15 \%)\end{array}$ \\
\hline $\begin{array}{c}\text { Generation time } \\
\text { (hour) }\end{array}$ & 3.18 & 2.99 & 3.08 & 3.05 & 3.08 & 3.16 \\
$\begin{array}{c}\text { Specific growth } \\
\text { rate (per hour) }\end{array}$ & 0.19 & 0.3 & 0.24 & 0.27 & 0.24 & 0.18 \\
\hline
\end{tabular}

\section{CONCLUSION}

Variation of enrichment and isolation media facilitates the isolation of diverse hydrocarbonoclastic bacteria which were able to degrade saturated, aromatic, resinic, and asphaltic fraction of crude oil. The highest bacterial diversities were obtained from the enrichment medium B (carbon source of crude oil supplemented with sodium lactate) and isolation medium I (nutrient agar with double agar), each resulted in $37 \%$ and $33 \%$ of isolates, respectively. In addition this study shows that the sequential isolation method can be one of promising method for bacterial isolation that will be used for MEOR application. ABG2-7 isolate was able to degrade heavy crude oil, thus might serve as the high potential bacteria for MEOR.

\section{ACKNOWLEDGEMENTS}

The authors would like to thank Oil and Gas Recovery for Indonesia (OGRINDO) ITB for providing samples and to the Ministry of Research, Technology \& Higher Education for facilitating and funding this research.

\section{REFERENCES}

Aditiawati, P. \& Kamarisima, K. 2015. Isolation of asphaltenedegrading bacteria from sludge oil. Makara Journal of Science 19(1): 13-20.
Amann, R.I., Ludwig, W. \& Schleifer, K.H. 1995. Phylogenetic identification and in situ detection of individual microbial cells without cultivation. Microbiology Reviews 59(1): 143-169.

Ariadji, T., Astuti, D.I., Aditiawati, P., Purwasena, I.A., Persada, G.P., Soeparmono, M.R., Amirudin, N.H., Ananggadipa, A.A., Sasongko, S.Y., Abqory, M.H., Ardianto, R.N., Subiantoro, E. \& Aditya, G.H. 2017. Microbial huff and puff project at Mangunjaya field wells: The first in Indonesia towards successful MEOR implementation. In SPE/IATMI Asia Pacific Oil \& Gas Conference and Exhibition. Jakarta, Indonesia.

Aske, N., Kallevik, H. \& Sjöblom, J. 2001. Determination of saturate, aromatic, resin, and asphaltenic (SARA) components in crude oils by means of infrared and nearinfrared spectroscopy. Energy \& Fuels 15(5): 1304-1312.

Astuti, D.I., Purwasena, I.A., Aditiawati, P., Sani, I., Ariadji, T. \& Abqory, M. 2017. Potential degradation of SARA (saturated, aromatics, resinics, asphaltenes) fractions of crude oil by reservoir indigenous bacteria from South Sumatera. Microbiology Indonesia 11(4): 137-146.

Benedek, T., Máthé, I., Táncsics, A., Lányi, S. \& Márialigeti, K. 2010. Investigation of hydrocarbon-degrading microbial communities of petroleum hydrocarbon contaminated soils in Harghita county, Romania. Scientific Bulletin Series D: Mining, Mineral Processing, Non-Ferrous Metallurgy, Geology and Environmental Engineering 24(2): 15. 
Das, N. \& Chandran, P. 2011. Microbial degradation of petroleum hydrocarbon contaminants: An overview. Biotechnology Research International 2011: Article ID. 941810.

Davidova, I.A. \& Suflita, J.M. 2005. Enrichment and isolation of anaerobic hydrocarbon-degrading bacteria. Methods in Enzymology 397: 17-34.

Davidova, I., Hicks, M.S., Fedorak, P.M. \& Suflita, J.M. 2001. The influence of nitrate on microbial processes in oil industry production waters. Journal of Industrial Microbiology and Biotechnology 27(2): 80-86.

Gailiūte, I., Račkauskienè, G. \& Grigiškis, S. 2014. Changes in crude oil hydrocarbon composition during biodegradation by Arthrobacter sp. M1 and Acinetobacter sp. Pr82 in selected optimal conditions. Biologija 60(3): 134-141.

Ghribi, D., Zouari, N. \& Jaoua, S. 2004. Improvement of bioinsecticides production through mutagenesis of Bacillus thuringiensis by uv and nitrous acid affecting metabolic pathways and/or delta - endotoxin synthesis. Journal of Applied Microbiology 97(2): 338-346.

Halim, A.Y., Fauzi, U.D., Siregar, S., Soewono, E., Gunawan, A.Y., Astuti, D.I. \& Juli, N. 2009. Microbial enhanced oil recovery: An investigation of bacteria ability to live and alter crude oil physical characteristics in high pressure condition. In Asia Pacific Oil and Gas Conference \& Exhibition. Jakarta, Indonesia. pp. 786-793.

Hedin, R.S. \& Watzlaf, G.R. 1994. The effects of anoxic limestone drains on mine water chemistry. In Proceedings, 3rd International Conference on the Abatement of Acidic Drainage. Pittsburgh: U.S. Bureau of Mines. pp. 185-194.

Islas-Flores, C.A., Buenrostro-Gonzalez, E. \& Lira-Galeana, C. 2005. Comparisons between open column chromatography and HPLC SARA fractionations in petroleum. Energy \& Fuels 19(5): 2080-2088.

Kamagata, Y. 2015. Keys to cultivating uncultured microbes: Elaborate enrichment strategies and resuscitation of dormant cells. Microbes and Environments 30(4): 289-290.

Ke, C.Y., Lu, G.M., Li, Y.B., Sun, W.J., Zhang, Q.Z. \& Zhang, X.L. 2018. A pilot study on large-scale microbial enhanced oil recovery (MEOR) in Baolige Oilfield. International Biodeterioration \& Biodegradation 127: 247-253.

Kemp, P.F. \& Aller, J.Y. 2004. Bacterial diversity in aquatic and other environments: What $16 \mathrm{~S}$ rDNA libraries can tell us. FEMS Microbiology Ecology 47(2): 161-177.

Lacy, R.C. 1987. Loss of genetic diversity from managed populations: Interacting effects of drift, mutation, immigration, selection, and population subdivision. Conservation Biology 1(2): 143-158.

Madigan, M.T., Martinko, J.M., Bender, K.S., Buckley, D.H. \& Stahl, D.A. 2015. Brock Biology of Microorganisms. 14th Ed. Boston: Pearson.

Maliji, D., Olama, Z. \& Holail, H. 2013. Environmental studies on the microbial degradation of oil hydrocarbons and its application in Lebanese oil polluted coastal and marine ecosystem. International Journal of Current Microbiology and Applied Science 2(6): 1-18.

Mandri, T. \& Lin, J. 2007. Isolation and characterization of engine oil degrading indigenous microrganisms in Kwazulu-Natal, South Africa. African Journal of Biotechnology 6(1): 23-27.

Ollivier, B. \& Cayol, J.L. 2005. The fermentative, iron-reducing, and nitrate-reducing microorganisms. In Petroleum Microbiology, edited by Ollivier, B. \& Magot, M. Washington DC: ASM Press. pp. 71-88.
Purwasena, I.A., Sugai, Y. \& Sasaki, K. 2014. Petrotoga japonica sp. nov., a thermophilic, fermentative bacterium isolated from Yabase Oilfield in Japan. Archives of Microbiology 196(5): 313-321.

Purwasena, I.A., Sugai, Y. \& Sasaki, K. 2009. Estimation of the potential of an oil-viscosity-reducing bacteria, Petrotoga sp., isolated from an oilfield for meor. In International Petroleum Technology Conference Proceeding (IPTC), 2009. Doha, Qatar.

Riss, T.L., Moravec, R.A., Niles, A.L., Duellman, S., Benink, H.A., Worzella, T.J. \& Minor, L. 2016. Cell viability assays. In Assay Guidance Manual. Bethesda, MD, USA: Eli Lilly \& Company.

Röling, W.F.M., Head, I.M. \& Larter, S.R. 2003. The microbiology of hydrocarbon degradation in subsurface petroleum reservoirs: perspectives and prospects. Research in Microbiology 154(5): 321-328.

Santos, R.G., Loh, W., Bannwart, A.C. \& Trevisan, O.V. 2014. An overview of heavy oil properties and its recovery and transportation methods. Brazilian Journal of Chemical Engineering 31(3): 571-590.

Sarkar, J., Kazy, S.K., Gupta, A., Dutta, A., Mohapatra, B., Roy, A. \& Sar, P. 2016. Biostimulation of indigenous microbial community for bioremediation of petroleum refinery sludge. Frontiers in Microbiology 7: 1407.

Shibulal, B., Al-Bahry, S.N., Al-Wahaibi, Y.M., Elshafie, A.E., AlBemani, A.S. \& Joshi, S.J. 2018. Microbial-enhanced heavy oil recovery under laboratory conditions by Bacillus firmus BG4 and Bacillus halodurans BG5 isolated from heavy oil fields. Colloids and Interfaces 2(1): 1.

Sierra-Garcia, I.N. \& de Oliveira, V.M. 2013. Microbial hydrocarbon degradation: Efforts to understand biodegradation in petroleum reservoirs. Biodegradation-Engineering and Technology. doi.org/10.5772/55920.

Spini, G., Spina, F., Poli, A., Blieux, A.L., Regnier, T., Gramellini, C., Varese, G.C. \& Puglisi, E. 2018. Molecular and microbiological insights on the enrichment procedures for the isolation of petroleum degrading bacteria and fungi. Frontiers in Microbiology 9: 2543.

Xu, X., Liu, W., Tian, S., Wang, W., Qi, Q., Jiang, P., Gao, X., Li, F., Li, H. \& Yu, H. 2018. Petroleum hydrocarbon-degrading bacteria for the remediation of oil pollution under aerobic conditions: A perspective analysis. Frontiers in Microbiology 9: 2885.

Yernazarova, A., Kayirmanova, G., Baubekova, A. \& Zhubanova, A. 2016. Microbial enhanced oil recovery. In Chemical Enhanced Oil Recovery (cEOR) - A Practical Overview. InTech. pp. 147-167.

Department of Microbiology

School of Life Science and Technology

Bandung Institute of Technology

Jalan Ganesha 10, Bandung West Java

Indonesia

*Corresponding author; email: isty@sith.itb.ac.id

Received: 15 January 2020

Accepted: 10 May 2020 